\title{
Rediscovering the Bhore Committee Report
}

"Health for all by $2000 \mathrm{AD}$ " is a theme well known to all health professionals. It was enunciated at Alma Ata in 1978. Most present day physicians fail to realise that remarkably similar recommendations were made by the Bhore Committee appointed in 1943. Joseph Bhore, an Indian ICS officer from Maharashtra was its chairman, Dr. KCKE Raja was the secretary and eminent persons such as K.T. Jungalwala, J.B. Grant, B.C. Roy, P.N. Sapru and A.L. Mudaliar were its members. This report is not easily available. Therefore, we publish an analysis of this report, with discussion of its relevance today by Ravi Duggal of the Foundation for Research in Community Health, Bombay. The main principles underlying the Bhore Committee proposals for health devclopment in India are summarized below.

1. No individual should fail to secure adequate medical care because of inability to pay for it.

2. In view of the complexity of modern medical practice, the health services should provide, when fully developed, all the consultant, laboratory and institutional facilities necessary for proper diagnosis and treatment.

3. The health programme must, from the beginning, lay special emphasis on preventive work. The creation and maintenance of as healthy an environment as possible in the homes of the people, as well as in all places where they congregate for work, amusement or creation, is essential. So long as environmental hygiene is neglected, so long as the faulty modes of life of the individuals and of the community remain uncorrected, so long as these and other factors weakening man's powcr of resistance and increasing his susceptibility to diseasc are allowed to operate unchecked, so long will our towns continue to be factories for the supply of cases to our hospitals and dispensaries.

4. The need is urgent for providing as much medical relief and preventive health care as possible to the vast rural population of the country. The debt which India owes to the tiller of the suil is immense and although he pays the heaviest toll when famine and pestilence sweep through the land, the medical attention he receives is of the most meagre description.

5. The health services should be placed as close to the people as possible in order to ensure the maximum benefit... to the communities to be served. The unit of health administration should therefore be made as small as is compatible with practical considerations.

6. ...The idea must be inculcated that, ultimately, the health of the individual is his own responsibility and, in attempting to do so, the most effective means would seem to be to stimulate his health consciousness by providing health education on the widest possible basis, as wcll as opportunitics for his active participation in the local health programme.

7....Both in respect of legislation and of administration it is likely that some of the measures to be undertaken may offend 
cxisting social and religious practices, while others may involve control over the day to day life of the citizen. We, therefore feel that it is only a Minister enjoying the confidence of the people who can carry such enactments through the legislature and ensure their practical application in the country.

It is heartening to note that the Bhore Committee made recommendations essentially similar to Alma Ata declaration of
1978 almost 30 years before it. However, it is sad that we are still grappling with the same problems and our achievements are much below of what is desirable. Those in charge of health plans must perform and achicve, rather than develop more plans!

\section{TOWARDS AN "IDEAL CHILDREN'S VACCINE”}

A major effort has been launched towards the development of an "ideal children's vaccine" that could save millions of children in the developing world. The major challenges include the need to :

- find altcrnatives to the repeated administrations required by many existing vaccines, which reduce vaccination coverage because of drop-out and increase the operational costs of immunization programmes;

- replace vaccines administered by injection with orally administered vaccines to reduce chances of contamination;

- combine different vaccines into a one-dose or one-shot vaccine, instead of the current requirement for many childhood immunizations;

- find new vaccines for diseases which have no effective vaccines, such as dengue, rotavirus diarrhoea, hepatitis $A$, hepatitis $E$, acute respiratory infections, bacterial diarrhoea, meningococcal meningitis and malaria;

- reduce the cnormous cost of bringing a single multicomponent vaccine to the market. 